\title{
Bats (Mammalia, Chiroptera) from Yuscarán in Eastern Honduras: Conservation and acoustic characterization for the insectivorous species
}

\author{
Wilson Noel Gómez-Corea ${ }^{1,4,6}$; Farlem Gabriel Españaa ${ }^{2}{ }^{7}$; David Josué Mejía-Quintanilla ${ }^{3,4,8}$ \& Andrea Nicole Figueroa-Grande ${ }^{4,5,9}$ \\ 1 Universidade Estadual de Santa Cruz (UESC), Programa de Pós-Graduação em Zoologia. Ilhéus, BA, Brasil. \\ ${ }^{2}$ Mesoamerican Development Institute (MDI). Lowell, Massachusetts, United States and Tegucigalpa, Honduras. \\ 3 Fundación en Ciencias para el Estudio y Conservación de la Biodiversidad (INCEBIO). Tegucigalpa, Francisco Morazán, Honduras. \\ ${ }^{4}$ Programa de Conservación de los Murciélagos de Honduras (PCMH). Tegucigalpa, Francisco Morazán, Honduras. \\ ${ }^{5}$ Instituto Nacional de Desarrollo y Conservación Forestal, Áreas Protegidas y Vida Silvestre (ICF), \\ Programa Nacional de Reforestación. Tegucigalpa, Francisco Morazán, Honduras. \\ ${ }^{6}$ ORCID: http://orcid.org/0000-0003-3145-258X. E-mail:wilsongomezcorea@gmail.com (corresponding author) \\ 7 ORCID: http://orcid.org/0000-0002-1395-8096. E-mail: efarlem@yaho0.com \\ ${ }^{8}$ ORCID: http://orcid.org/0000-0002-2774-4849. E-mail: davidmejia93@hotmail.es \\ ${ }^{9}$ ORCID: http://orcid.org/0000-0002-2729-5967. E-mail: anfigueroa16@gmail.com
}

\begin{abstract}
In Honduras, most bat inventories have been carried out with mist nets as the main sampling method, skewing knowledge towards the Phyllostomidae family, therefore the diversity and distribution of insectivorous bats is underrepresented. In order to have a more complete knowledge of the diversity of bats in the municipality of Yuscarán and mainly in the Yuscarán Biological Reserve, an inventory was carried out using the techniques of mist-netting and acoustic monitoring. The samplings were carried out between 910 and 1,827 m.a.s.l., covering agroecosystems, broadleaf forest, pine forest and urban environment. A total of 32 species of bats were registered, which represents $28 \%$ of the species diversity present in Honduras. Species belonging to five families were recorded: Emballonuridae (6.25\%), Mormoopidae (15.22\%), Phyllostomidae (56.25\%), Molossidae (9.37\%) and Vespertilionidae (12.5\%). With the mist nets, a sampling effort of 7,128 $\mathrm{m}^{2} / \mathrm{h}$ was reached, which allowed the capture of 20 species and 186 individuals. Through the acoustic method, with $84 \mathrm{~h} / \mathrm{r}, 13$ species of insectivorous bats were recorded. The values of the acoustic parameters analysed from the search phase of each insectivorous species are provided, which can serve as a reference for the identification of species from Hondurans. To advance our understanding of the distribution patterns, composition, and vocal signatures of insectivore bats, we suggest the complementary use of mist nets and acoustic recorders in the inventories.
\end{abstract}

Keywords. Biological Reserve; Central America; Insectivorous bats; Acoustic sampling; Echolocation.

\section{INTRODUCTION}

Bats (order Chiroptera), with more than 1,400 species are after of rodents, the second-largest group of mammals in the world (Simmons, 2005; Fenton \& Simmons, 2014; Solari et al., 2019). They represent approximately half of the diversity of mammalian species in tropical forests (Simmons \& Voss, 1998; Estrada \& Coates-Estrada, 2001; Aguirre, 2002). Bats carry out important and complex ecological processes in forests, since they act as important pest controllers, pollinators and seed dispersers, including several plant species used by humans (Medellín \& Gaona, 1999; Aguirre, 2002; Kunz et al., 2011). Furthermore, they are used as indicators of the quality, biodiversity and disturbance of ecosystems and due to their ecological role, they contribute to the restoration of disturbed areas, secondary succession and re-establishment of primary forest species (Stevens \& Willig, 2000; Botto-Nuñez et al., 2019; García-Luis et al., 2019). Despite their importance, they face multiple threats: habitat loss and fragmentation, loss of roosting sites, disease, pesticide use, wind farms and rabies control (Mickleburgh et al., 2002; RELCOM, 2010; Botto-Nuñez et al., 2019).

In the Neotropical region, monitoring of bats depends to a great part on the use of mist nets, skewing knowledge towards the Phyllostomidae family (Kalko et al., 1996). Therefore, many aspects 
of the non-Phyllostomid species (insectivores), that are difficult to capture with traditional methods, or that are found in inaccessible sites, are still unknown (Kalko et al., 1996). These aerial insectivorous bat species are a diverse group and typically use specialized echolocation calls and are able to easily detect and avoid mist nets or fly too high above the tree canopy (MacSwiney et al., 2008; Marques et al., 2015). The echolocation calls are emitted and used to orient themselves in flight, detect and capture prey; in addition the vocalizations have a social character, being the product of adaptations to specific environments, which provides valuable information for the knowledge of biology and ecology of insectivorous species (Arita \& Fenton, 1997; Neuweiler, 2000). At present, in the Neotropical region, the number of ecological studies and inventory of bat species that involve the use of echolocation detectors has increased due to the greater availability and a wide variety of acoustic detection, recording and analysis equipment (Jung et al., 2007; Barataud et al., 2013; Jung et al., 2014).

In Honduras, the eastern region and specifically the municipality of Yuscarán, constitutes an area of great importance for the conservation of Honduran biodiversity due to this it was included within the Union Biological Corridor (JICA, 2018), and was designated as an "Área de Importancia para la Conservación de los Murciélagos" (AICOM), with 37 registered species (Mejía et al., 2019).
Although the municipality of Yuscarán is forested, currently the landscape has been modified due to the pressures exerted on the forested areas, with the loss of habitat being the main threat. Promoting the management and conservation of bats in Yuscarán requires knowledge of the species found there. For this reason, our objective was to record the taxonomic diversity of bats present in this region, using mist nets and acoustic recording, in different ecosystems. This allows us to know and qualitatively and quantitatively characterize the calls of insectivorous bats in the search phase, which can serve as a reference for future bioacoustics studies in Honduras.

\section{MATERIAL AND METHODS}

\section{Study area}

Honduras has a territorial extension of $112,492 \mathrm{~km}^{2}$ divided into 18 departments. In the eastern zone of Honduras is located the department of El Paraíso, to which the Municipality of Yuscarán belongs with a territorial extension of $348.9 \mathrm{~km}^{2}$ and has a protected area, the Yuscarán Biological Reserve (YBR), (Fig. 1). Originally the YBR had a total area of $41.87 \mathrm{~km}^{2}$, however this was extended, since approximately $21 \mathrm{~km}^{2}$ were added (JICA, 2018). The average annual temperature is $\sim 24.5^{\circ} \mathrm{C}$

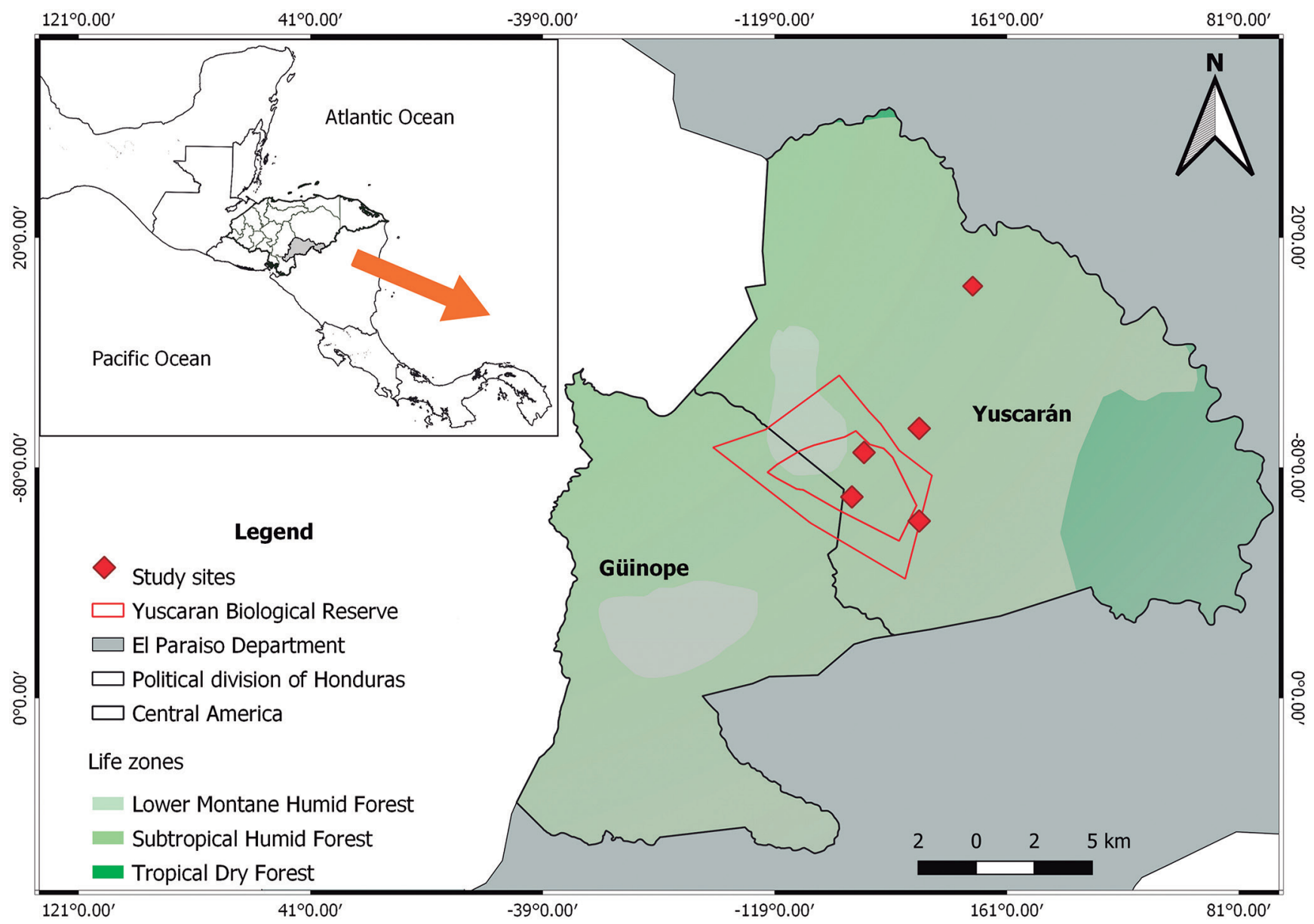

Figure 1. Geographic location of the study sites in the Yuscarán Biological Reserve and Municipality of Yuscarán, Department of El Paraíso, Honduras, Central America. Geographic coordinates and other details are in Table 1. 
Table 1. Sampling locations with their respective geographic information, sampling efforts $\mathrm{m}^{2} / \mathrm{h}$ (SE), number of individuals captured by each sampling site (IC), Richness observed (RO) and Average richness (AR).

\begin{tabular}{|c|c|c|c|c|c|c|c|c|c|c|}
\hline Locality & Latitude N & Longitude W & m.a.s.l & SE & IC & RO & Chao 1 & Jack 1 & Bootstrap & AR \\
\hline Laínez & $14^{\circ} 00^{\prime} 8.28^{\prime \prime}$ & $86^{\circ} 49^{\prime} 12^{\prime \prime}$ & 929 & 972 & 14 & 4 & 8,06 & 7,78 & 7,78 & 7,87 \\
\hline Antennas & $13^{\circ} 55^{\prime} 0.53^{\prime \prime}$ & $86^{\circ} 52^{\prime} 28^{\prime \prime}$ & 1827 & 2592 & 30 & 7 & 14,36 & 19,18 & 16,5 & 16,68 \\
\hline Cave & $13^{\circ} 55^{\prime} 59.3^{\prime \prime}$ & $86^{\circ} 52^{\prime} 06^{\prime \prime}$ & 1716 & 2592 & 36 & 7 & 17,9 & 24,18 & 20,58 & 20,88 \\
\hline Agro-ecosystem & $13^{\circ} 54^{\prime} 39.1^{\prime \prime}$ & $86^{\circ} 50^{\prime} 56^{\prime \prime}$ & 1151 & 972 & 106 & 16 & 20,6 & 28,25 & 23,75 & 24,2 \\
\hline Urban environment & $13^{\circ} 56^{\prime} 42.0^{\prime \prime}$ & $86^{\circ} 51^{\prime} 02^{\prime \prime}$ & 910 & $84^{*}$ & & 13 & & & & \\
\hline
\end{tabular}

* Acoustic sampling effort (hours recording).

and the average annual precipitation in the area is $\sim$ 1,562.2 $\mathrm{mm}$ (elevations $>1,000$ meters above sea level m.a.s.l., with ranges greater than 2,000 mm), (AFOCO, 2001; JICA, 2018). Less than $14 \%$ of the total area of the reserve is covered by dense broadleaf forest, $21 \%$ by intervened broadleaf forest, $10 \%$ by mixed forest and about $14 \%$ corresponds to pine forest; the remaining area destined for subsistence agriculture or coffee growing (AFOCO, 2001). In this area, five field samplings were carried out, in five previously defined study sites, in an altitudinal range of 910 to 1,827 m.a.s.l., covering different ecosystems: agroecosystems, broadleaf forest, pine forest and urban environment (Table 1).

\section{Mist nets and species classifications}

The field data were obtained between December 2017 to November 2019. We used the mist-netting technique, with a length of $12 \mathrm{~m}$ and $9 \mathrm{~m}$ long $\times 3 \mathrm{~m}$ high, (38 $\mathrm{mm}$ mesh), ground-level ( 0.5-4 $\mathrm{m}$ height). We surveyed two nights at each site with an operating time of 17:00 to 24:00 hours, with nets cheked for captured bats at 15 minute intervals. The mist nets were located ad libitum, taking into account the characteristics of the sampled locations, trails, glades, near streams, caves, and shelters (Kunz et al., 2009) and avoiding the days close to the full moon (Saldaña-Vázquez \& Munguía-Rosas, 2013). Standard morphometric measurements $(\mathrm{mm})$ and body mass $(\mathrm{g})$ were taken from each captured bat. The measurements were made in millimetres, with a digital caliper to $0.01 \mathrm{~mm}$ accuracy, and body mass, using a Pesola spring scale (20, 50 and $100 \mathrm{~g}$ capacity). The bats captured in the mist nets were individually placed in cloth bags for later handling. For taxonomic identification, we used reference descriptions, comparing external measurements with the works of Timm et al. (1999); Medellín et al., (2008); Reid (2009) and Medina-Fitoria (2014). Each individual captured was classified according to the sex class (males and females), age (adults and juveniles), determined by the degree of ossification of the pharyngeal epiphyses (Brunet-Rossini \& Wilkinson, 2009) and reproductive status (female: non-reproductive, pregnant, lactating, post-lactating; male: enlarged and descended testicles: scrotal or non-scrotal) Racey (2009). After their identification and taking a photograph, the bats were released. Bats were captured and handled in the field following guidelines approved by the American Society of Mammalogists (Sikes \& the Animal Care and Use
Committee of the American Society of Mammalogists, 2016).

For bat species named in our study, we followed the currently valid taxonomic nomenclature as outlined in Wilson \& Mittermeier (2019) and Simmons \& Cirranello (2020). For the genus Sturnira, Velazco \& Patterson (2013) was followed, Dermanura is considered as a separate genus from Artibeus (Hoofer et al., 2008), and Glossophaga soricina represents a taxonomic complex and the valid species is adopted, Calahorra-Oliart et al. (2021). The arrangement of the family Mormoopidae follows Pavan \& Marroig (2016) and the genus Molossus follows Loureiro et al. $(2019,2020)$. The species were classified according to the primary feeding guild based on the works of Kalko et al. (1996), Schnitzler \& Kalko (2001), Schnitzler et al. (2003), and the guilds are: Insectivore (I); Animalivore (A); Frugivore (F); Nectarivore (N); Omnivore (O); Hematophagous (H). The conservation status was assigned according to the Red List of Threatened Species of the International Union for Conservation of Nature (IUCN), considering the following categories: Critically Endangered (CR); Endangered (EN); Vulnerable (VU); Threatened (NT); Least Concern (LC); No data (NC) (IUCN, 2021).

\section{Bioacoustic recording and analysis}

A bat recorder (Song Meter SM3Bat + ) was used with an omnidirectional ultrasound microphone SMX-US (Wildlife Acoustics, Maynard, Massachusetts, USA). The recorder was installed in open urban areas at a height of approximately one meter above ground level, with an inclination of $45^{\circ}$ (Adams et al., 2012) oriented towards the flight path of the bats. All vocalizations were recorded through the heterodyne system, with frequencies between 20 and $100 \mathrm{kHz}$ and in a WAV (Waveform Audio Format) audio format. The recordings started at 18:00 hours and ended at 6:00 hours, on nights without strong winds or rain (Parsons \& Szewczak, 2009). The Kaleidoscope software (version 5.1.9) (Wildlife Acoustics, Maynard, Massachusetts, USA) was used to visualize the spectrograms. Kaleidoscope settings were as follows: FFT size 256, window size 128 and cache size $256 \mathrm{MB}$. Recordings with very weak bat passes or indistinguishable callout passes were excluded. We define the sample unit as a 'bat pass', to a sequence with a minimum of two recognizable echolocation pulses per species (Azam et al., 2015; Millon et al., 2015). 
Bat calls were manually identified through a series of acoustic characteristics and standard measurements: maximum frequency (Fmax), minimum frequency (Fmin), mean frequency (Fmean), characteristic frequency $(\mathrm{Fc})$, characteristic slope (Sc), duration of each pulse (Dur). Finally, the structure (shape) and quantitative characteristics of the vocalizations were compared with reference works by Kalko (1995); O'Farrell \& Miller (1997); Miller (2003); Barataud et al., 2013; Jung et al. (2007, 2014), MacSwiney et al. (2008); Orozco-Lugo et al. (2013); Gómez-Corea et al. (2021) and the records of a reference acoustic library, obtained from previous monitoring in different regions of Honduras, using the hand release method in open areas; recordings at the exit of the shelters and in flight rooms. Functional traits of insectivorous bats that will be used to describe the structure of calls: frequency modulated (FM), quasi-constant frequency (QCF), constant frequency (FC) and frequency maximum energy (FME) (Schnitzler \& Kalko, 2001; Schnitzler et al., 2003).

\section{Analysis of data}

The species accumulation curve was calculated to measure the effectiveness of the inventory (Fig. 2). Previously, the samples were randomized 100 times with the software Estimates version 9.1.0 (Colwell, 2013) to avoid the order effect and smooth the curve (Moreno \& Halffter, 2000). The percentage of representativeness was calculated using the Chao 1 (Chao \& Lee, 1992), Jacknife 1 (Walther \& Moore, 2005) and Bootstrap estimators these being regarded as particularly suitable for extrapolating richness estimates within biological communities (Colwell \& Coddington, 1994; Walther \& Moore, 2005; Hortal et al., 2006). The completeness of the inventory was obtained by calculating the percentage of species observed with respect to those calculated by the estimators (Moreno \& Halffter, 2000). Following Sodhi et al. (2005), we take the mean value of these three estimators (rounded to the nearest integer value) as an estimate of "true" species richness, since the effectiveness of the dif-

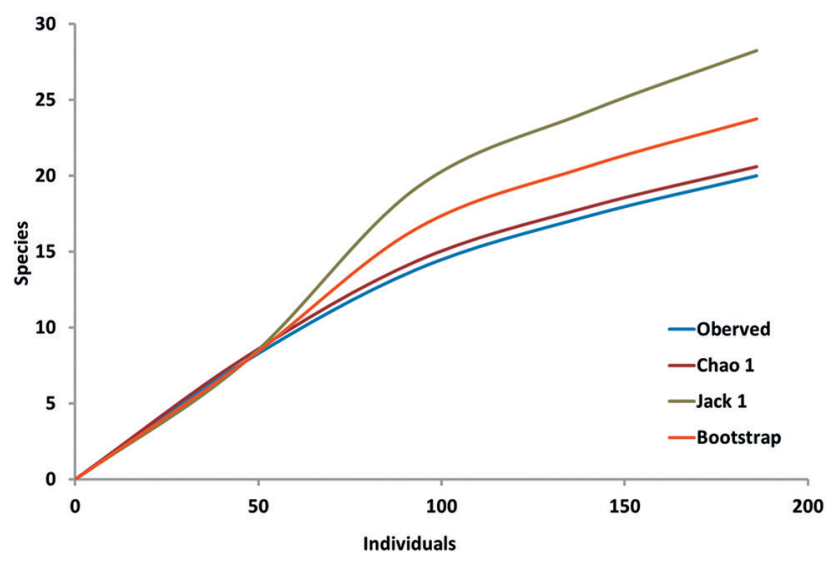

Figure 2. Species accumulation curve using mist nets, in the Yuscarán Biological Reserve and Municipality of Yuscarán, Department of El Paraíso, Honduras, Central America. ferent estimators varies according to the composition of the data set. The sampling effort was calculated by multiplying the number of hours that the nets were kept open by the area of the nets $\left(\mathrm{m}^{2}\right)$, (Straube \& Bianconi, 2002).

\section{RESULTS}

\section{Registered species}

Thirty-two species of bats belonging to 5 families and 19 genus were recorded (Table 2). The Phyllostomidae family was the most diverse (18 species; $56.25 \%$ ), followed by the Mormoopidae Family (5 species; $15.22 \%$ ). The least diverse families were Vespertilionidae (4 species; $12.5 \%$ ), Molossidae (3 species; $9.37 \%$ ) and finally the Emballonuridae family ( 2 species; 6.25\%). Using mist nets with a sampling effort of $7,128 \mathrm{~m}^{2} / \mathrm{h}, 20$ species were captured, with a total of 186 individuals, and the proportion of the sex class favoured males with 103 males and 83 females (Fig. 3). Regarding the age class, 149 adults and 37 juveniles were captured. The species accumulation curve obtained with the mist nets did not show a stabilizing trend, indicating that the number of species would have increased if we had sampled more nights. The relationship between the observed wealth and the estimated wealth according to the estimators: Chao 1, 97.69\%; Jacknife 1, 70.79\% and Bootstrap 84.21\%.

According to the qualitative and quantitative characteristics of the ultrasounds emitted by the bats, 13 species belonging to the families Emballonuridae, Mormoopidae, Molosidae and Vespertilionidae were identified. The Fig. 4 shows the pulses of the echolocation calls emitted by insectivorous species during the foraging phase and Table 3 the quantitative characteristics of the pulses. Species from 6 trophic guilds were recorded: insectivorous $(I=14)$, frugivorous $(F=10)$, nectarivorous $(\mathrm{N}=4)$, animalivorous $(A=2)$, omnivorous $(\mathrm{O}=1)$, and haematophagous $(\mathrm{H}=1)$.

\section{Acoustic characterization of aerial insectivorous species}

Family Emballonuridae: based on their vocal signatures, we identified two species, which do not show overlap in the average frequency measurements and are characterized by emitting QCF pulses, with an initial or terminal FM component and with 3 harmonics, of which the second is the fundamental. Balantiopteryx plicata, emits pulses, with a final FM segment, the averages of the Fmax-Fim are 41.09-39.94 kHz and a Fc of $40.33 \mathrm{kHz}$, while Peropteryx macrotis for the same frequencies 39.18-37.82 kHz and $38.55 \mathrm{kHz}$ in the dominant harmonic. Family Mormoopidae: we identify and describe four species, with a basic component arrangement, CF-FM-QCF. For the identification of Pteronotus gymnonotus and $P$. fulvus, the range of Fmax-Fmin was considered since the calls of the first species were located on average between $53.99-45.04 \mathrm{kHz}$ and the second be- 
Table 2. List of species captured using the mist-netting technique (individuals captured IC) and acoustic recordings (indicated with *), also shows the respective primary feeding guild (GT) and the state of conservation of the IUCN.

\begin{tabular}{|c|c|c|c|c|c|c|c|}
\hline Family & Sub Family & Species & IC & $\sigma^{*}$ & q & FG & IUCN \\
\hline \multirow[t]{2}{*}{ Emballonuridae } & Emballonurinae & Balantiopteryx plicata Peters, $1867^{*}$ & & & & 1 & LC \\
\hline & & Peropteryx macrotis (Wagner, 1843)* & & & & 1 & $\mathrm{LC}$ \\
\hline \multirow[t]{5}{*}{ Mormoopidae } & & Mormoops megalophylla (Peters, 1864) & 2 & 2 & 0 & 1 & LC \\
\hline & & Pteronotus fulvus (Thomas, 1982)* & & & & 1 & $\mathrm{LC}$ \\
\hline & & Pteronotus gymnonotus (J.A. Wagner, 1843)* & & & & 1 & $\mathrm{LC}$ \\
\hline & & Pteronotus mesoamericanus Smith, $1972^{*}$ & & & & 1 & $\mathrm{LC}$ \\
\hline & & Pteronotus psilotis (Dobson, 1878)* & & & & 1 & $\mathrm{LC}$ \\
\hline \multirow[t]{18}{*}{ Phyllostomidae } & Micronycterinae & Micronycteris hirsuta (Peters, 1869). & 2 & 1 & 1 & A & LC \\
\hline & Desmodontinae & Desmodus rotundus (É. Geoffroy, 1810) & 10 & 5 & 5 & $\mathrm{H}$ & LC \\
\hline & Lonchorhininae & Lonchorhina aurita Tomes, 1863 & 1 & 1 & 0 & A & $\mathrm{LC}$ \\
\hline & Phyllostominae & Phyllostomus discolor Wagner, 1843 & 2 & 2 & 0 & 0 & $\mathrm{LC}$ \\
\hline & Glossophaginae & Anoura geoffroyi Gray, 1838 & 3 & 3 & 0 & $\mathrm{~N}$ & $\mathrm{LC}$ \\
\hline & & Choeroniscus godmani (Thomas, 1903) & 1 & 1 & 0 & $\mathrm{~N}$ & $\mathrm{LC}$ \\
\hline & & Glossophaga mutica Merriam 1898 & 30 & 10 & 20 & N & LC \\
\hline & & Glossophaga leachii Gray, 1844 & 10 & 5 & 5 & $\mathrm{~N}$ & $\mathrm{LC}$ \\
\hline & Carolliinae & Carollia perspicillata (Linnaeus, 1758) & 20 & 10 & 10 & $\mathrm{~F}$ & $\mathrm{LC}$ \\
\hline & & Carollia sowelli Baker, Solari \& Hoffmann, 2002 & 10 & 5 & 5 & $\mathrm{~F}$ & $\mathrm{LC}$ \\
\hline & & Carollia subrufa (Hahn, 1905) & 24 & 14 & 10 & $\mathrm{~F}$ & $\mathrm{LC}$ \\
\hline & Stenodermatinae & Artibeus jamaicensis Leach, 1821 & 19 & 14 & 5 & $\mathrm{~F}$ & $\mathrm{LC}$ \\
\hline & & Artibeus lituratus (0lfers, 1818) & 17 & 9 & 8 & $\mathrm{~F}$ & LC \\
\hline & & Chiroderma salvini Dobson, 1878. & 1 & 1 & 0 & $\mathrm{~F}$ & $\mathrm{LC}$ \\
\hline & & Dermanura azteca K. Andersen, 1906. & 2 & 2 & 0 & $\mathrm{~F}$ & $\mathrm{LC}$ \\
\hline & & Dermanura phaeotis (Miller, 1902) & 9 & 5 & 4 & $\mathrm{~F}$ & LC \\
\hline & & Sturnira hondurensis Goodwin, 1940 & 12 & 6 & 6 & $\mathrm{~F}$ & $\mathrm{LC}$ \\
\hline & & Sturnira parvidens Goldman, 1917 & 8 & 4 & 4 & $\mathrm{~F}$ & $\mathrm{LC}$ \\
\hline \multirow[t]{3}{*}{ Molossidae } & Molossinae & Molossus alvarezi Gonzalez-Ruiz, Ramirez-Pulido \& Arroyo-Cabrales, 2011* & & & & 1 & $\mathrm{LC}$ \\
\hline & & Molossus molossus (Pallas, 1766)* & & & & 1 & LC \\
\hline & & Molossus nigricans Miller, $1902^{*}$ & & & & 1 & $\mathrm{LC}$ \\
\hline \multirow[t]{4}{*}{ Vespertilionidae } & Myotinae & Myotis nigricans $(S c h i n z, 1821)^{*}$ & & & & 1 & $\mathrm{LC}$ \\
\hline & Vespertilioninae & Eptesicus brasiliensis (Desmarest, 1819)* & & & & 1 & $\mathrm{LC}$ \\
\hline & & Eptesicus furinalis (d'Orbigny, 1847)* & & & & 1 & $\mathrm{LC}$ \\
\hline & & Eptesicus fuscus (Beauvois, 1796) ${ }^{* *}$ & 3 & 3 & 0 & I & $\mathrm{LC}$ \\
\hline
\end{tabular}

** Acoustic recording and mist net capture.

Table 3. Acoustic parameters analysed from echolocation calls during the search phase of insectivore bats.

\begin{tabular}{|c|c|c|c|c|c|c|c|}
\hline Species & $\begin{array}{c}\text { Number } \\
\text { of calls }\end{array}$ & $\begin{array}{l}\text { Fmax } \\
(\mathbf{k H z})\end{array}$ & $\begin{array}{l}\text { Fmin } \\
(\mathrm{kHz})\end{array}$ & $\begin{array}{c}\text { Fmean } \\
(\mathrm{kHz})\end{array}$ & $\mathrm{Fc}(\mathrm{kHz})$ & Sc & $\begin{array}{l}\text { Dur } \\
\text { (ms) }\end{array}$ \\
\hline \multicolumn{8}{|l|}{ Emballonuridae } \\
\hline B. plicata & 12 & 41.09 & 39.94 & 40.49 & 40.33 & 7.47 & 4.04 \\
\hline P. macrotis & 33 & 39.18 & 37.82 & 38.36 & 38.55 & 1.61 & 6.05 \\
\hline \multicolumn{8}{|l|}{ Mormoopidae } \\
\hline P. fulvus & 18 & 57.13 & 48.26 & 53.20 & 55.93 & -5.87 & 4.78 \\
\hline P.gymnonotus & 17 & 53.99 & 45.04 & 50.72 & 52.81 & 6.36 & 5.55 \\
\hline P. mesoamericanus & 15 & 61.30 & 59.18 & 59.18 & 60.47 & -3.03 & 6.94 \\
\hline P.psilotis & 10 & 74.09 & 64.02 & 68.22 & 68.59 & 23.06 & 4.32 \\
\hline \multicolumn{8}{|l|}{ Molossidae } \\
\hline M. alvarezi & 12 & 34.79 & 32.83 & 33.69 & 33.51 & 5.17 & 6.51 \\
\hline M. molossus & 18 & 32.50 & 30.31 & 31.51 & 31.87 & 1.81 & 5.52 \\
\hline M. nigricans & 17 & 31.20 & 25.66 & 28.05 & 25.42 & 21.18 & 6.63 \\
\hline \multicolumn{8}{|l|}{ Vespertilionidae } \\
\hline M. nigricans & 10 & 63.28 & 49.04 & 51.96 & 49.26 & 12.38 & 3.60 \\
\hline E. brasiliensis & 12 & 35.59 & 31.49 & 32.84 & 31.87 & 24.74 & 2.96 \\
\hline E. furinalis & 7 & 59.53 & 46.45 & 49.75 & 46.79 & 43.78 & 2.39 \\
\hline E. fuscus & 20 & 45.51 & 30.53 & 34.95 & 31.27 & 47.73 & 4.76 \\
\hline
\end{tabular}

tween $57.13-48.26 \mathrm{kHz}$, with an Fc of $55.93 \mathrm{kHz}$ and the pulse with a "Z" shape. Pteronotus mesoamericanus has a range of Fmax-Fim of $61.30-59.18 \mathrm{kHz}$ and pulses lasting 6.94 ms. Pteronotus psilotis, presents averages of Fmax 74.09 and Fim 64.02 and the pulses have a "Z" shape.

Family Molossidae: we identify and characterize three species of the genus Molossus, which are characterized by emitting FM or CF pulses and by presenting an overlap of the calls in the search phase in the Fmax and Fmin, but with well-marked differences in the Sc. The averages of the parameters of Fmax-Fmin and Sc: 34.79-32.82, 5.17 for M. alvarezi; 32.50-30.31, 1.81 for M. molossus and $31.20-25.66,21.18 \mathrm{kHz}$ for $M$. nigricans, the pulses of the latter species are modulated in FM in the first part of the call, while the rest is CF. Family Vespertilionidae: based on their vocal signatures, we identify and characterize four species, one species from the genus Myotis and three from the genus Eptesicus, which are characterized by emitting pulses of FM structure, sometimes with an QCF ending. For the identification of the species of the genus Eptesicus, Fmin was considered and later the shape of the pulses. The Fmax-Fmin and Dur was: $63.28-49.04$ kHz 
and $3.60 \mathrm{~ms}$ for M. nigricans; $35.59-31.49 \mathrm{kHz}$ and $2.96 \mathrm{~ms}$ for E. brasiliensis; $59.53-46.45 \mathrm{kHz}$ and $2.39 \mathrm{~ms}$ for $E$. furinalis and $45.51-30.53 \mathrm{kHz}$ and $4.76 \mathrm{~ms}$ for E. fuscus, this last species the Fmin presents a partial overlap with E. brasiliensis.

\section{DISCUSSION}

\section{Vocalizations of insectivorous bats}

The species registered in the YBR and the municipality of Yuscarán, represent $28 \%$ of the 113 species of bats reported for Honduras (Turcios-Casco et al., 2020; Mora et al., 2021). It is evidenced once again that the mist net is the best method to capture bats of the Phyllostomidae family (nectarivorous, frugivorous and hematophagous), (Kalko et al., 1996) and that acoustic detectors are devices very useful for registering insectivorous bats. The calls of aerial insectivorous bats are highly variable due to numerous factors, such as the type of activity, the surrounding environmental disorder, search behaviour, the acoustic complexity of the emitted sound, the number of sequences analysed and the availability of material for comparison (Faure \& Barclay, 1994; Simmons \& O'Farrell, 1977). According to Jiang et al. (2010), some geographic or intraspecific variations of the calls show allelic discontinuity between populations, which suggests a genet-

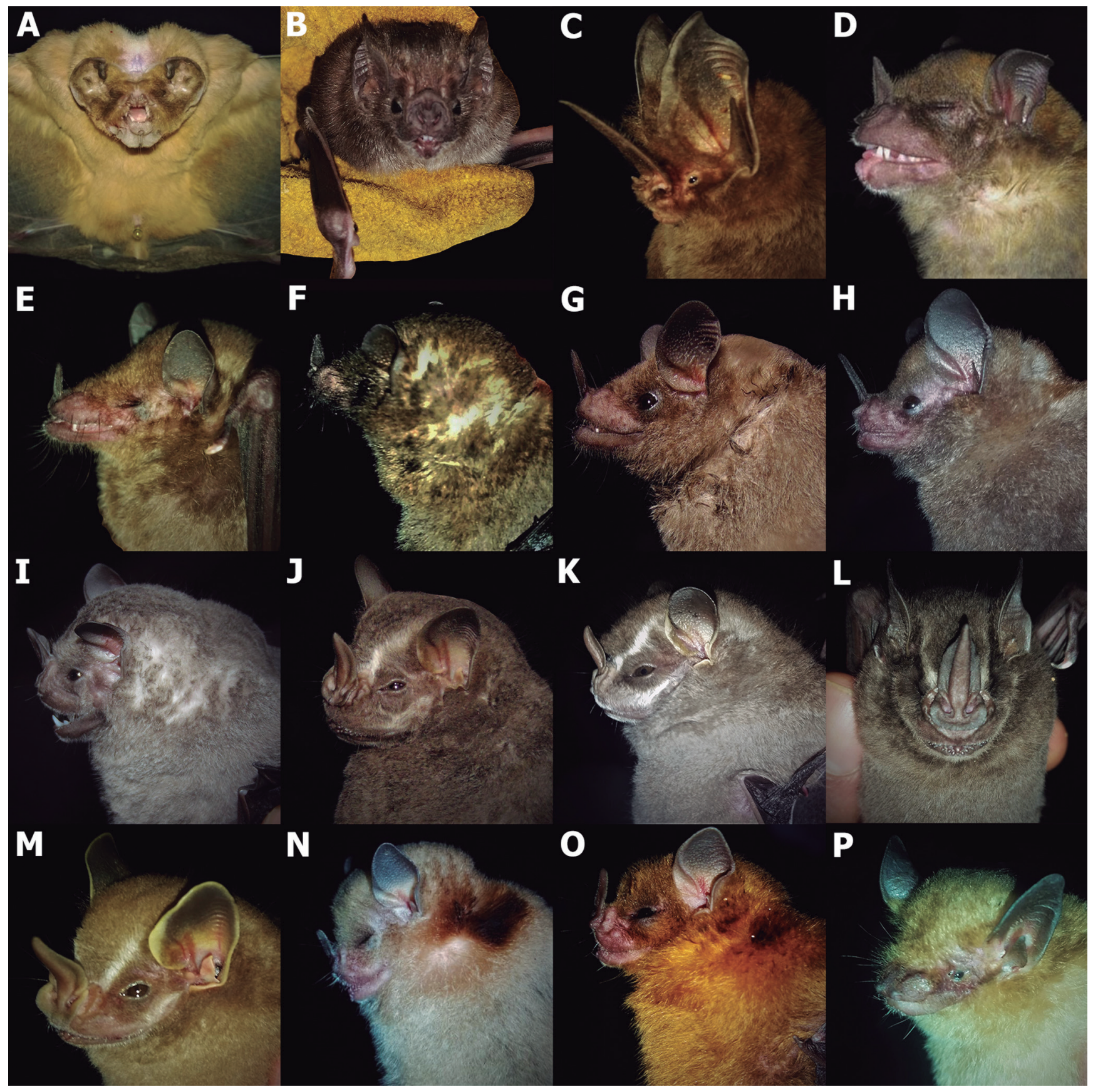

Figure 3. Part of the bat species captured with mist nets, in the Yuscarán Biological Reserve and Municipality of Yuscarán, Department of El Paraíso, Honduras, Central America. (A) M. megalophylla; (B) D. rotundus; (C) L. aurita; (D) P. discolor; (E) A. geoffroyi; (F) G. leachii; (G) G. mutica; (H) C. perspicillata; (I) A. jamaicensis; (J) A. lituratus; (K) C. salvini; (L) D. azteca; (M) D. phaeotis; (N) S. hondurensis; (O) S. parvidens; (P) E. fuscus. Photos: (C) D.J.M.Q.; (A-P) W.N.G.C. 
ic basis for these differences. These variations can lead to the overlapping of the characteristics of the calls of certain species that can complicate their identification. The complexity tends to be even greater with forest species, which mostly emit low intensity broadband FM signals (Siemers \& Schnitzler, 2004). For the families Emballonuridae and Mormoopidae, the acoustic identification of the species seems to be simple (O'Farrell \& Miller, 1997, 1999), whereas it can be complicated for the family Vespertilionidae and Molossidae.

The echolocation calls in the family Emballonuridae are multi-harmonic; however, the energy distribution differs strongly since the FME of the search calls resides mainly in the second harmonic or in the higher harmonics (Jung et al., 2007; Arias-Aguilar et al., 2018). B. plicata and $P$. macrotis exhibit a different Fc that allows them to be discriminated from the rest of the emballonurid bats
(Williams-Guillén \& Perfecto, 2011). For B. plicata, the Fmax and Fim that we document is within that recorded by Briones-Salas et al. (2013) and partially coincides with that of García-Luis \& Briones-Salas (2017), both are sequences of individuals in Mexico. While Jung et al. (2007), for this same species in Costa Rica and Panama register maximum frequencies around $42.60 \pm 0.80 \mathrm{kHz}$, (Peak frequency). In P. macrotis, the averages of the parameters fit with the frequencies documented by Miller (2003), in Belize, the Fmax and Fmin fit the one documented by Barataud et al. (2013) in Guyana, partially with those registered by Briones-Salas et al. (2013) in Mexico and with the FME values around $38.9 \pm 0.91 \mathrm{kHz}$ in Panama and Costa Rica (Jung et al., 2007). The bandwidth of search calls for emballonurid bats flying in rim space is still narrow compared to molossid and vespertilionid bats where it can extend 30-50 kHz or more (e.g., Schnitzler \& Kalko,
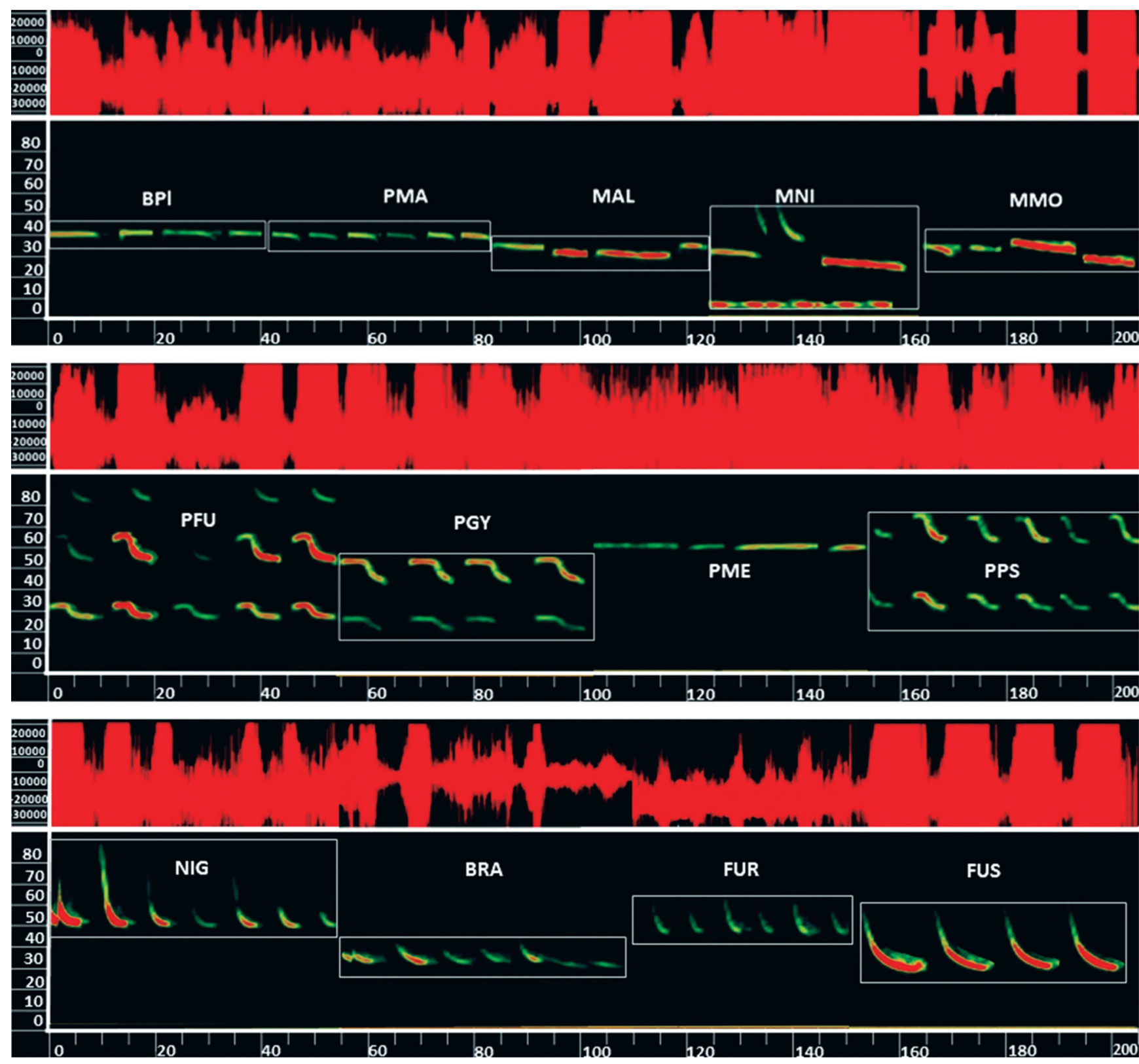

Figure 4. Echolocation pulses of aerial insectivorous bats. Spectrograms (bottom) and oscillograms (top) correspond to search calls. X axis milliseconds (ms) and $Y$ axis Kilohertz (kHz). Emballonuridae: (BPI) B. plicata, (PMA) P. macrotis; Molossidae: (MAL) M. alvarezi, (MNI) M. nigricans, (MM0) M. molossus. Mormoopidae: (PFU) P. fulvus, (PGY) P. gymnonotus, (PME) P. mesoamericanus, (PPS) P. psilotis. Vespertilionidae: (NIG) M. nigricans, (BRA) E. brasiliensis, (FUR) E. furinalis, (FUS) E. fuscus. 
2001; Siemers et al., 2001). The frequency stratification between the species of this family constitutes a perfect example of acoustic niches within this group; the vocalizations of each species have undergone a displacement to avoid interspecific overlap (Barataud et al., 2013).

The echolocation in the species of family Mormoopidae, can be easily recognized, since their vocalizations are considered as acoustic signatures. They can exhibit pulses made up of an easily recognizable CF or FM, with very characteristic shapes of each species, and there is practically no problem during the assignment of species (Miller, 2003; Williams-Guillén \& Perfecto, 2011). In general, the calls we recorded were multi-harmonic, the FME is in the second harmonic and the pulses have at least one CF section. Pteronotus fulvus differs $7 \mathrm{kHz}$ below the range documented in Belize and in Mexico by O'Farrell \& Miller (1997), Miller (2003) and Ibáñez et al. (1999) (cited as, P. davyi Gray, 1838). Pteronotus psilotis, fits with respect to the frequencies previously described in the region, (Fmax between $72-87 \mathrm{kHz}$ and Fmin between 60-69 kH), (O'Farrell \& Miller, 1997; Miller, 2003) (cited as P. personatus (Wagner, 1843)).

In the family Molossidae, the species are characterized by emitting low FM pulses and have an FME in fundamental harmonics with long surface modulation signals emitted at quite low frequencies (Jung et al., 2014). These species usually show irregular frequency alternation, narrowband, variable amplitude and great plasticity (Arias-Aguilar et al., 2018). According to Jung et al. (2014), the wide frequency range emitted by some molossid bats is related to foraging strategies, allowing these species a greater feeding success. Regarding some species, identification at the species level is complicated due to the lack of reference calls in the literature and the overlap of frequency parameters (Williams-Guillén \& Perfecto, 2011). Even so, the genus Molossus is easily identified by the paired pattern of the pulses (Miller, 2003). In this study, M. molosus, presented frequencies similar to those of low frequencies registered by Miller (2003), nevertheless the frequencies found here contrast with the descriptions of O'Farrell \& Miller (1999), which provide a mean frequency of $34.1 \mathrm{kHz}$ for the lowest pulses and $39.7 \mathrm{kHz}$ for the highest frequency. M. nigricans emitted vocalizations that are within the range documented by GómezCorea et al. (2021) in different regions of Honduras, and conforms to the portion of high frequency recorded by Miller (2003), the Fmax and Fmin coincide with that reported by Kraker-Castañeda et al. (2013) in Mexico, (cited as $M$. rufus). It should be noted the presence of these three species in urban environments, it can be attributed to the fact that some species of this genus have a certain adaptive plasticity to disturbance conditions (Jung \& Kalko, 2011).

The differentiating of the species in the Vespertilionidae family is particularly difficult, and some authors recommend using Fmin, FME and Dur as diagnostic characters (O'Farrell \& Miller, 1999; Williams-Guillén \& Perfecto 2011; Arias-Aguilar et al., 2018). According to Williams-Guillén \& Perfecto (2011), the genus Myotis emits Fmin between $48 \mathrm{kHz}$ and $58 \mathrm{kHz}$ and the identifi- cation is complicated due to the superposition of parameters, in this case the Fmin that we found for M. nigricans was $49.04 \mathrm{kHz}$. M. nigricans presents a call structure, with narrow bandwidth and quite long signals adapted to the search for food predominantly in open spaces, it is also capable of searching aerial food with short broadband signals in edge and space situations, emitting an average maximum energy peak frequency of 54.2 (Siemers et al., 2001). In general, the calls of the genus Eptesicus are bilinear, with a clear break in the slope that precedes the flat part of the call, and they are also separated by the Fmin (Miller, 2003). The frequencies recorded here for E. furinalis fit with studies carried out by Miller (2003), and Kraker-Castañeda et al. (2013), who record a range of Fmax and Fmin between 64.02-32.78, in this regard Rydell et al., (2002) mentions that most of the energy is between $36 \pm 41 \mathrm{kHz}$. The average of Fmax and Fmin that we report for E. fuscus was $45.51-30.53 \mathrm{kHz}$, similar to that reported by León-Tapia \& Hortelano-Moncada (2016) of 53.44-32.79 kHz in Mexico. The variations in the Fmax and Fmin can be attributed to the adaptation of the vocal repertoires, to the feeding sites in different habitats and prey, and the reproductive status of females (Gillam \& McCracken, 2007).

\section{Conservation efforts}

In the study area, the main threat to biodiversity and in particular to bat species is the loss of habitat (JICA, 2018). The population increase in the municipality of Yuscarán from 2013 to 2018 was from 14,144 to 15,572 inhabitants (INE, 2013), and this causes enormous pressure on diversity, through the development of livestock activities and the advancement of traditional agriculture and technified (Mejía-Ordoñez, 2013; JICA, 2018). The YBR is part of the Union Biological Corridor (UBC), where the forest cover has decreased, and the agricultural area increased (JICA, 2018), further worsening the situation the high rates of erosion due to the absence of protection practices and soil improvement (AFOCO, 2001; Martinez-Garcia, 2002). The dense pine forest area decreased $7,850.6$ ha (11.2\% of the UBC area) and the scrub area 7,139.6 ha (10.2\% of the UBC area) during the last 25 years, while the agricultural area increased 11,347.9 ha (16.2\%) from 1987 to 2011 (JICA, 2018) and the pine forest was affected by the pine bark beetle (Mejía et al., 2019).

In this fragmented landscape framework, the diversity of bats recorded here plays an important role, since they must be considered as part of the solution to connect patches of vegetation. Phyllostomid bats, especially the frugivorous and nectarivorous species, are fundamental in these ecosystems for the dispersal of seeds and pollination of plants both in disturbed and conserved areas (Stevens \& Willig, 2000; García-Luis et al., 2019). Insectivorous bats are using Yuscarán as a feeding site since we record hunting events determined from feeding trains (Griffin et al., 1960) have been recorded, indicating the possible capture of prey (Bogdanowicz et al., 1999). Especially the presence of the species of the genus Myotis 
and Eptesicus since their diet may include insects that are considered pests (Tuttle \& Moreno, 2005). Therefore, the conservation of forest remnants is of utmost importance to sustain the pest control ecosystem service that bats are providing to crops in the area (Boyle et al., 2011). For this region, some conservation efforts have already been established, as it is recognized as an AICOMS, however, to develop more effective conservation, the unified effort of local, regional and national organizations is necessary. Being necessary to strengthen the institutional framework (both public and private), which is explicitly associated with environmental issues, (universities, companies, NGOs, etc.) and develop an educational communication strategy linked to environmental education.

Undoubtedly, it is necessary to carry out more studies in the YBR and surroundings to know the possible fluctuations of the bat populations, implementing monitoring in the medium and long term, in addition in this sampling design did not include several months of the year and therefore, effort sampling may be insufficient to detect some species and in some calls analysed the samples are not representative to see the full range of vocalization of insectivorous bats. In Honduras, new studies should employ include methods for the upper stratum, using a combination of acoustic methods and mist nets (Gómez-Corea et al., 2020), focusing on standardized acoustic monitoring that provides information to create an acoustic reference library. The range of variation inherent in the vocal repertoire of each species should be established, given the relevance of geographic variation and intraspecific and interspecific variations. This will allow the knowledge of the vocal signatures of the species which will be a useful tool to carry out fast and accurate inventories, establishing patterns of activity, habitat use and other aspects of the behavioural ecology of bat communities (Kalko, 1995).

\section{ACKNOWLEDGMENTS}

We thank the following people and institutions for the support they gave us: Yuscarán Foundation; Japan International Cooperation Agency (JICA) within the framework of the Union Biological Corridor Project; UNAH Vertebrate Laboratory; MDI; Eduin Castellanos; Rafael Centeno; Ana Banegas; Lowin Caballero; Romero Mazariegos; Mariela Rodríguez; Dominic Boquín and Jocelyn Castro, who collaborated in the field surveys. To Martín R. Alvarez, Gustavo Pavón from the Unidad Municipal Ambiental (UMA), from the municipality of Yuscarán and anonymous reviewers for helpful comments and suggestions on the manuscript. To the Fundação de Amparo à Pesquisa do Estado da Bahia (FAPESB) for the fellowship.

\section{AUTHORS' CONTRIBUTIONS}

W.N.G.C.; F.G.E. and D.J.M.Q., design and implementation of the investigation. W.N.G.C., formal analysis, writing - original draft. W.N.G.C., F.G.E., D.J.M.Q. and A.N.F.G., carried out the field work, writing and revision. All authors contributed to the analysis of the results, reviewed and approved the final version of the paper.

\section{CONFLICTS OF INTEREST}

Authors declare there are no conflicts of interest.

\section{REFERENCES}

Adams, A.M.; Jantzen, M.K.; Hamilton, R.M. \& Fenton, M.B. 2012. Do you hear what I hear? Implications of detector selection for acoustic monitoring of bats. Methods in Ecology and Evolution, 3(6): 992-998. D0I

AFOCO [Proyecto de apoyo a la forestaría comunitaria] 2001. Plan de manejo de la Reserva Biológica de Yuscarán 2000-2004. Honduras, Yuscarán. 65p.

Aguirre, L.F. 2002. Structure of a neotropical savanna bat community. Journal of Mammalian, 83(3): 775-784. D0I

Arias-Aguilar, A.; Hintze, F.; Aguiar, L.M.; Rufray, R.; Bernard, E. \& Ramos P.M.J. 2018. Who's calling? Acoustic identification of Brazilian bats. Mammal Research, 63(3): 231-253. DOI

Arita, H.T. \& Fenton M.B. 1997. Flight and echolocation in the ecology and evolution of bats. Trends in Ecology \& Evolution, 12: 53-58. DOI

Azam, C.; Kerbiriou, C.; Vernet, A.; Julien, J.F.; Bas, Y.; Plichard, L.; Maratrat, J. \& Le Viol, I. 2015. Is part-night lighting an effective measure to limit the impacts of artificial lighting on bats? Global Change Biology, 21(12): 4333-4341. DOI

Barataud, M.; Giosa, S.; Leblanc, F.; Rufray, V.; Disca, T.; Tillon, L.; Delaval, M.; Haquart, A.\&Dewynter, M. 2013. Identification et écologie acoustiquedes chiroptères de Guyane Française. Le Rhinolophe, 19: 103-145.

Bogdanowicz, W.; Fenton M.B. \& Daleszczyk, K. 1999. The relationships between echolocation calls, morphology and diet in insectivorous bats. Journal of Zoology, 247(3): 381-393. D0I

Botto-Nuñez, G.; Gonzales, M.E. \& Rodales, A.L. 2019. Conservación de los murciélagos (Mammalia: Chiroptera) de Uruguay: Estado actual y perspectivas. Mastozoología Neotropical, 26: 49-64. D0I

Boyle, J.G.; Cryan, P.M.; McCracken, G.F. \& Kunz, T.H. 2011. Economic importance of bats in agriculture. Science, 332: 41-42. D0I

Briones-Salas, M.; Peralta-Pérez, M. \& García-Luis, M. 2013. Acoustic characterization of new species of bats for the State of Oaxaca Mexico. Therya, 4: 15-32. D0I

Brunet-Rossini, A.K. \& Wilkinson, G.S. 2009. Methods for age estimation and the study of senescence in bats. In: Kunz, T.H. \& Parsons, S. (Eds.). Ecological and behavioral methods for the study of bats. Baltimore, Johns Hopkins University Press. p. 315-325.

Calahorra-Oliart, A.; Ospina-Garcés, S.M. \& León-Paniagua, L. 2021. Cryptic species in Glossophaga soricina (Chiroptera: Phyllostomidae): do morphological data support molecular evidence? Journal of Mammalogy, 102: 54-68. DOI

Chao, A. \& Lee, S.M. 1992. Estimating the number of classes via sample coverage. Journal of the American Statistical Association, 87(417): 210-217. D0I

Colwell, R.K. 2013. EstimateS, Version 9.1: statistical estimation of species richness and shared species from samples (Software and User's Guide). Freeware for Windows and Mac OS. Available: http://viceroy.eeb.uconn. edu/EstimateS/EstimateSPages/EstSUsersGuide/EstimateSUsersGuide. htm. Access: 20/04/2021.

Colwell, R.K. \& Coddington, J.A. 1994. Estimating terrestrial biodiversity through extrapolation. Philosophical Transactions of the Royal Society B: Biological Sciences, 345(1311): 101-118. DO| 
Estrada, A. \& Coates-Estrada, R. 2001. Species composition and reproductive phenology of bats in a tropical landscape at Los Tuxtlas, Mexico. Journal of Tropical Ecology, 17(5): 627-646. D0I

Faure, P.A. \& Barclay, R.M.R. 1994. Substrate-gleaning versus aerial-hawking: plasticity in the foraging and echolocation behaviour of the long-eared bat, Myotis evotis. Journal of Comparative Physiology A, 174(5): 651-660. D0I

Fenton, M.B. \& Simmons, N.B. 2014. Bats: a world of science and mystery. Chicago, University of Chicago Press,. pp. 305.

García-Luis, M. \& Briones-Salas, M. 2017. Composición y actividad de la comunidad de murciélagos artropodívoros en parques eólicos del trópico mexicano. Revista Mexicana de Biodiversidad, 88(4): 888-898. D0I

García-Luis, M.; Briones-Salas, M. \& Lavariega, M.C. 2019. Bat species richness in the region of the Central Valleys of Oaxaca, Mexico. Arxius de Miscellania Zoologica, 17: 1-11. DOI

Gillam, E.H. \& McCracken, G.F. 2007. Variability in the echolocation of Tadarida brasiliensis: effects of geography and local acoustic environment. Animal Behaviour, 74(2): 277-286. DOI

Gómez-Corea, W.; Hernández, J.; Antúnez-Fonseca, C.; Mejía-Quintanilla, D. \& Vega, H. 2021. Leucism and updated geographic distribution of Molossus nigricans Miller, 1902, (Chiroptera: Molossidae) In Honduras. Mammalia, 85: 64-70. DOI

Gómez-Corea, W.; Mejía-Quintanilla, D.; Hernández, J.; Vallejo-Ham, A.E.; Flores, R. \& Figueroa-Grande, A. 2020. Diclidurus albus Wied-Neuwied, 1819 (Mammalia, Chiroptera): geographic distribution in Honduras, with new records inferred from acoustic evidence and morphology. Caribbean Journal of Science, 50(2): 265-274. D0I

Griffin, D.R.; Webster, F.A. \& Michael, C.R. 1960. The echolocation of flying insects by bats. Animal Behaviour, 8: 141-154. DOI

Hoofer, S.R.; Solari, S.; Larsen, P.A.; Bradley, R.D. \& Baker, R.J. 2008. Phylogenetics of the fruit-eating bats (Phyllostomidae: Artibeina) inferred from mitochondrial DNA sequences. Occasional Papers Museum Texas Tech University, 277: 1-15. D0I

Hortal, J.; Borges, P.A.V. \& Gaspar, C. 2006. Evaluating the performance of species richness estimators: sensitivity to sample grainsize. Journal of Animal Ecology, 75(1): 274-287. D0I

Ibáñez, C.; Guillén, A.; Juste, J. \& Pérez-Jordá, J.L. 1999. Echolocation calls of Pteronotus davyi (Chiroptera: Mormoopidae) form Panamá. Journal of Mammalogy, 80: 924-928. D0I

INE [Instituto Nacional de Estadística]. 2013. XVII Censo de Poblacion y VI de Vivienda 2013. Tomo 91, Municipio de Yuscarán 07-01. Available: https:// www.ine.gob.hn/V3/imag-doc/2018/05/Tomo-91-Municipio-deYuscar\%C3\%A1n-07-01.pdf. Access: 01/03/2021.

International Union for Conservation of Nature and Natural Resources (IUCN). 2021. Version 2021-1. The IUCN Red List of Threatened Species. Available: https://www.iucnredlist.org. Access: 15/03/2021.

Jiang, T.; Metzner, W.; You, Y.; Liu, S.: Lu G.; Li, S.; Wang, L. \& Feng, J. 2010. Variation in the resting frequency of Rhinolophus pusillus in Mainland China: effect of climate and implications for conservation. The Journal of the Acoustical Society of America, 128(4): 2204-2211. D01

JICA [Agencia de Cooperación Internacional del Japón]. 2018. Proyecto Corredor Biológico de La Unión, para el uso sostenible y conservación de la biodiversidad. DiBio-MiAmbiente/JICA. 318p. Available: https://www.jica.go.jp/project/spanish/honduras/004/materials/ c8h0vm0000bk9y9y-att/materials 10.pdf. Access: 05/02/2021.

Jung, K. \& Kalko, E.K.V. 2011. Adaptability and vulnerability of high flying Neotropical aerial insectivorous bats to urbanization. Diversity and Distribution, 17(2): 262-274. D0I

Jung, K.; Kalko, E.K.V. \& von Helversen, 0. 2007. Echolocation calls in Central American emballonurid bats: Signal design and call frequency alternation. Journal of Zoology, 272(2): 125-137. D01
Jung, K.; Molinari, J. \& Kalko, E.K.V. 2014. Driving factors for the evolution of species-specific echolocation call design in new world free-tailed bats (Molossidae). PLOS ONE, 9: e85279. DOI

Kalko, E.K.V. 1995. Echolocation signal design, foraging habitats and guild structure in six Neotropical sheath-tailed bats (Emballonuridae). Symposia of the Zoological Society of London, 67: 259-273.

Kalko, E.K.V.; Handley, C.0. \& Handley, D. 1996. Organization, diversity, and long term dynamics of a Neotropical bat community. In: Cody, M. \& Smallwood, J. (Eds.). Long term studies in vertebrate communities. Academic Press. p. 503-553.

Kraker-Castañeda, C.; Santos-Moreno, A. \& García-García, J.L. 2013. Riqueza de especies y actividad relativa de murciélagos insectívoros aéreos en una selva tropical y pastizales en 0axaca, México. Mastozoología Neotropical, 20(2): 255-267.

Kunz, T.H.; Hodgkison, R. \& Weise, C. 2009. Methods of capturing and handling bats. In: Kunz, T.H. \& Parsons, S. (Eds.). Ecological and behavioral methods for the study of bats. 2.ed. Baltimore, Johns Hopkins University Press. p. 3-35.

Kunz, T.H.; Torrez, E.B.; Bauer, D.; Lavoba, T. \& Fleming, T.H. 2011. Ecosystem services provided by bats. Annals of the New York Academy of Sciences, 1223: 1-38. DOI

León-Tapia, M.A. \& Hortelano-Moncada, Y. 2016. Richness of insectivorous bats in a chaparral area in the municipality of Tecate, Baja California, Mexico. Revista Mexicana de Biodiversidad, 87(3): 1055-1061. DOI

Loureiro, L.0.; Engstrom, M.; Lim, B.; López-González, C. \& Juste, J. 2019. Not all Molossus are created equal: genetic variation in the mastiff bat reveals diversity masked by conservative morphology. Acta Chiropterologica, 21: 51-64. DOI

Loureiro, L.0.; Engstrom, M.D. \& Lim, B.K. 2020. Single nucleotide polymorphisms (SNPs) provide unprecedented resolution of species boundaries, phylogenetic relationships, and genetic diversity in the mastiff bats (Molossus). Molecular Phylogenetics and Evolution, 143: 106690. DOI

MacsWiney, M.C.; Clarke, F.M. \& Racey, P.A. 2008. What you see is not what you get: the role of ultrasonic de tectors in increasing inventory completeness in Neotropical bat assemblages. Journal of Applied Ecology, 45: 1364-1371. D0I

Marques, J.T.; Ramos Pereira, M. \& Palmeirim, J. 2015. Patterns in the use of rainforest vertical space by Neotropical aerial insectivorous bats: all the action is up in the canopy. Ecography, 38: 001-011. D01

Martinez-Garcia, R.A. 2002. Análisis multitemporal de la cobertura vegetal de la Reserva Biológica de Yuscarán, El Paraiso, Honduras. Honduras, Zamorano. 42p. Available: https://bdigital.zamorano.edu/handle/11036/1585. Access: 05/03/2021.

Medellín, R.A. \& Geona, 0. 1999. Seed dispersal by bats and birds in forest and disturbed habitats of Chiapas, Mexico. Biotropica, 31(3): 478-485. DOI

Medellín, R.A.; Arita, H. \& Sánchez, 0. 2008. Identificación de los murciélagos de México. Clave de campo. Segunda Edición. Instituto de Ecología. Universidad Nacional Autónoma de México. 80p.

Medina-Fitoria, A. 2014. Murciélagos de Nicaragua, guía de campo. Managua, Nicaragua. MARENA/PCMN. 280p.

Mejía, D.; Elvir F.; Portillo, H. \& Flores, M. 2019. AlCOM A-H-006 Corredor Biológico La Unión. PCMH/RELCOM. 9p. Available: https://www. relcomlatinoamerica.net/\%C2\%BFqu\%C3\%A9-hacemos/conservacion/ aicoms-sicoms/aicoms-sicoms-buscador/ad/aicoms,1/la-union, 89. html. Access: 05/03/2021.

Mejía-Ordoñez, T.M. 2013. Composición florística en fragmentos de bosque en los municipios de Yuscarán, Oropoli y Güinope, Departamento de El Paraíso, Honduras, C.A. Revista de Ciencias Espaciales, 6: 7-22. DOI

Mickleburgh, S.P.; Hutson, A.M. \& Racey, P.A. 2002. A review of the global conservation status of bats. Oryx, 36: 18-34. D01 
Miller, B.M. 2003. Community ecology of the non-phyllostomid bats of Northwestern Belize, with a landscape level assessment of the bats of Belize (Doctoral Thesis). University of Kent Dureell Institute of Conservation and Ecology, UK.

Millon, L.; Julien, J.F.; Julliard, R. \& Kerbiriou, C. 2015. Bat activity in intensively farmed landscapes with wind turbines and offset measures. Ecological Engineering, 75: 250-257. DOI

Mora, J.M.; López, L.I. \& Espinal, M.R. 2021. Clave de campo para la identificación de los murciélagos de Honduras. Notas sobre Mamíferos Sudamericanos, 3: e21.6.1.

Moreno, C.E. \& Halffter, G. 2000. Assessing the completeness of bat biodiversity inventory using species accumulation curves. Journal of Applied Ecology, 37(1): 149-158. D0I

Neuweiler, G. 2000. Echolocation. In: Neuweiler, G. (Ed.). The Biology of bats. Oxford, Oxford University Press. p. 140-260.

0'Farrell, M.J. \& Miller, B.W. 1997. A new examination of echolocation calls of some Neotropical bats (Emballonuridae and Mormoopidae). Journal of Mammalogy, 78(3): 954-963. D01

O'Farrell, M.J. \& Miller, B.W. 1999. Use of vocal signatures for the inventory of free-flying neotropical bats. Biotropica, 31(3): 507-516. D0I

Orozco-Lugo, L.; Guillén-Servent, A.; Valenzuela-Galván, D. \& Arita, H.T. 2013. Descripción de los pulsos de ecolocalización de once especies de murciélagos insectívoros aéreos de una selva baja caducifolia en Morelos, México. Therya, 4(1):33-46. DOI

Parsons, S. \& Szewczak, J. 2009. Detecting, recording and analysing the vocalizations of bats. In: Kunz, T.H. \& Parsons, S. (Eds.). Ecological and behavioural methods for the study of bats. Baltimore, Johns Hopkins University Press.p. 91-111

Pavan, A.C. \& Marroig, G. 2016. Integrating multiple evidences in taxonomy: species diversity and phylogeny of mustached bats (Mormoopidae: Pteronotus). Molecular Phylogenetics and Evolution, 103: 184-198. D01

Racey, P.A. 2009. Reproductive assessment of bats. In: Kunz, T.H. \& Parsons, S. (Eds.). Ecological and behavioral methods for the study of bats. 2. ed. Maryland, The Johns Hopkins University Press. p. 249-264.

Reid, F.A. 2009. A field guide to the mammals of Central America and Southeast Mexico. 2.ed. Oxford University Press.

RELCOM [Red Latinoamericana de Conservación de los Murciélagos]. 2010. Estrategia para la conservación de los murciélagos de Latinoamérica y el Caribe. Available: http://www.relcomlatinoamerica.net/images/PDFs/ Estrategia.pdf (19 0ctober 2016). Access: 05/03/2021.

Rydell, J.; Arita, H.; Santos M. \& Granados, J. 2002. Acoustic identification of insectivorous bats (order Chiroptera) of Yucatan, Mexico. Journal of Zoology, 257: 27-36. DOI

Saldaña-Vázquez, R.A. \& Munguía-Rosas, M.A. 2013. Lunar phobia in bats and its ecological correlates: A meta-analysis. Mammalian Biology, 78(3): 216-219. DOI

Schnitzler, H.U. \& Kalko, E.K.V. 2001. Echolocation by insect-eating bats: we define four distinct functional groups of bats and find differences in signal structure that correlate with the typical echolocation tasks faced by each group. BioScience, 51(7): 557-569. DOI

Schnitzler, H.U.; Moss, C.F. \& Denzinger, A. 2003. From spatial orientation to food acquisition in echolocating bats. Trends Ecology \& Evolution, 18(8): 386-394. DOI

Siemers, B.M. \& Schnitzler, H.U. 2004. Echolocation signals reflect niche differentiation in five sympatric congeneric bat species. Nature, 429(6992): 657-661. DOI
Siemers, B.M.; Kalko, E.K.V. \& Schnitzler, H.U. 2001. Echolocation behavior and signal plasticity in the Neotropical bat Myotis nigricans (Schinz, 1821) (Vespertiionidae): a convergent case with European species of Pipistrellus? Behavioral Ecology Sociobiology, 50(4): 317-328. D0I

Sikes, R.S. \& the Animal Care and Use Committee of the American Society of Mammalogists. 2016. Guidelines of the American Society of Mammalogists for the use of wild mammals in research and education. Journal of Mammalogy, 97(3): 663-688. D0I

Simmons, J.A. \& O'Farrell, M.J. 1977. Echolocation by the long-eared bat, Plecotus phyllotis. Journal of Comparative Physiology, 122(2): 201-214. D0I

Simmons, N.B. 2005. Order Chiroptera. In: Wilson, D.E. \& Reeder, D.M. (Eds.). Mammal species of the World: a taxonomic and geographic reference. Baltimore, Johns Hop kins University Press. p. 1207.

Simmons, N.B. \& Cirranello A.L. 2020. Bat Species of the World: A taxonomic and geographic database. Available: https://batnames.org. Access: 08/03/2021.

Simmons, N.B. \& Voss, R.S. 1998. The mammals of Paracou, French Guiana: a Neotropical lowland rainforest fauna. Part 1. Bats. Bulletin of the American Museum of Natural History, 237: 1-219.

Sodhi, N.S.; Koh, L.P.; Prawiradilaga, D.M.; Tinulele, I.; Putra, D.D. \& Tan, T.H.T. 2005. Land use and conservation value for forest birds in central Sulawesi. Biological Conservation, 122(4): 547-558.

Solari, S.C.; Sotero, C.G. \& Backer R.J. 2019. Advances in systematics of bats: towards a consensus on species delimitation and classifications through integrative taxonomy. Journal of Mammalogy, 100(3): 838-851. D0I

Stevens, R.D. \& Willig, M.R. 2000. Density compensation in New World bat communities. Oikos, 89(2): 367-377. DOI

Straube, F.C. \& Bianconi, G.V. 2002. Sobre a grandeza e a unidade utilizada para estimar esforço de captura com utilização de redes de neblina. Chiroptera Neotropical, 8: 150-152.

Timm, R.M.; Laval, R.K. \& Rodrigues, B. 1999. Clave de campo para los Murciélagos de Costa Rica. Brenesia, 52: 1-32.

Turcios-Casco, M.A.; Avila-Palma, H.D.; LaVal, R.K.; Steven, R.D.; OrdoñezTrejo, E.J.; Soler-Orellana, J.A. \& Ordoñez-Mazier, D.I. 2020. A systematic revision of the bats (Chiroptera) of Honduras: an updated checklist with corroboration of historical specimens and new records. Zoosystematics and Evolution, 96(2): 411-429. D0I

Tuttle, M.D. \& Moreno, A. 2005. Los murciélagos cavernícolas del norte de México. Su importancia y problemas de conservación. Austin, Bat Conservation International. Available: http://centro.paot.org.mx/ documentos/varios/murcielagos.pdf. Access: 08/04/2021.

Velazco, P.M. \& Patterson, B.D. 2013. Diversification of the yellow-shouldered bats genus Sturnira (Phyllostomidae), in the new world tropics. Molecular Phylogenetics and Evolution, 68(3): 683-698. D0I

Walther, B.A. \& Moore, J.L. 2005. The concepts of bias, precision and accuracy, and their use in testing the performance of species richness estimators, with a literature review of estimator performance. Ecography, 28(6): 815-829. D0I

Williams-Guillén, K. \& Perfecto, I. 2011. Ensemble composition and activity levels of insectivorous bats in response to management intensification in coffee agroforestry Systems. PLOS ONE, 6: 1-10. DOI

Wilson, D.E. \& Mittermeier, R.A. 2019. Handbook of the mammals of the world. Barcelona, Lynx Ediciones. 